
\title{
25 Research Square \\ Tempol Differently Affects Cellular Redox Status and Antioxidant Enzymes in Various Lung-related Cells
}

woo hyun park ( $\nabla$ parkwh71@jbnu.ac.kr.ac.kr)

Jeonbuk National University

\section{Research Article}

Keywords: Tempol, Lung cancer cells, Human pulmonary fibroblast, Cell death, Reactive oxygen species, Glutathione, Thioredoxin reductase

Posted Date: March 3rd, 2021

DOI: https://doi.org/10.21203/rs.3.rs-257487/v1

License: (a) (i) This work is licensed under a Creative Commons Attribution 4.0 International License.

Read Full License

Version of Record: A version of this preprint was published at Scientific Reports on July 21st, 2021. See the published version at https://doi.org/10.1038/s41598-021-94340-z. 


\section{Abstract}

Tempol (4-hydroxy-2,2,6,6-tetramethylpiperidine-1-oxyl) is a potential redox agent in cells. The present study investigated changes in cellular redox status [reactive oxygen species (ROS) and glutathione (GSH) levels] and in antioxidant enzymes, in Tempol-treated Calu- 6 and A549 lung cancer cells, normal lung WI38 VA-13 cells, and primary pulmonary fibroblasts. Results demonstrated that Tempol $(0.5 \sim 4 \mathrm{mM})$ either increased or decreased general ROS levels in lung cancer and normal cells at $48 \mathrm{~h}$ and specifically increased $\mathrm{O}_{2}{ }^{\cdot-}$ levels in these cells. In addition, Tempol differentially altered the expression and activity of superoxide dismutase, catalase, and thioredoxin reductase1 (TrxR1) in A549, Calu-6, and WI-38 VA-13 cells. In particular, Tempol increased TrxR1 protein levels in these cells. Tempol at $1 \mathrm{mM}$ inhibited the growth of lung cancer and normal cells by about $50 \%$ at $48 \mathrm{~h}$ but also significantly induced cell death, as evidenced by annexin V-positive cells. Furthermore, down-regulation of TrxR1 by siRNA somewhat affected the levels of cell growth inhibition and death as well as ROS in Tempol-treated cells. In addition, Tempol increased the numbers of GSH-depleted cells in both cancer cells and normal cells at $48 \mathrm{~h}$. In conclusion, Tempol differentially increased or decreased levels of ROS and various antioxidant enzymes in lung cancer and normal cells, and induced growth inhibition and death in all lung cells along with an increase in $\mathrm{O}_{2}{ }^{--}$levels and $\mathrm{GSH}$ depletion.

\section{Introduction}

The human lung is a structurally multidimensional organ and is susceptible to countless forms of injuries, which are risk factors for developing lung diseases like fibrosis and cancer ${ }^{1}$. As a rule, the physiological restoration process in a healthy lung is constantly active, and usually following injury will repair lung structure and restore function. On the other hand, the progression of lung repair can be pathological, leading to impaired structure and function. Pulmonary fibroblasts (PF) are fundamentally involved in repair and restoration following injuries ${ }^{2}$. During pathological recovery of the lung, sparse or redundant recruitment of fibroblasts can cause tissue dysfunction and eventually pulmonary disease ${ }^{2}$. Lung cancer is one of the most common lung diseases and one of the most important contributors to cancer-related mortality worldwide ${ }^{3,4}$. Lung cancer consists mainly of either small cell lung cancer (SCLC) or non-SCLC (NSCLC) types, which make up $10-13 \%$ and $85-90 \%$ of all lung cancer cases, respectively ${ }^{3,4}$. Existing drugs available are still inadequate, and this has prompted a demand for upgraded therapeutic approaches. Among the chemotherapy options tested are cytotoxic drugs that target the cell death signaling process (i.e. apoptosis or necrosis) ${ }^{5,6}$. Numerous innovative methods for treating lung cancer are currently being developed and are under investigation ${ }^{7}$.

Reactive oxygen species (ROS) are very unstable oxygen molecules and include hydrogen peroxide $\left(\mathrm{H}_{2} \mathrm{O}_{2}\right)$, hydroxyl radicals $\left({ }^{\circ} \mathrm{OH}\right)$, and superoxide anions $\left(\mathrm{O}_{2}{ }^{\cdot-}\right)$ among others. These fundamental molecules are typically considered harmful to cells and tissues. However, ROS are contributory in regulating numerous cellular events such as gene expression, differentiation, and cell proliferation ${ }^{8,9}$. 
$\mathrm{ROS}$, and in particular $\mathrm{O}_{2}{ }^{\cdot-}$, are constantly generated during mitochondrial oxidative phosphorylation and unequivocally produced by specific oxidases including nicotinamide adenine dinucleotide phosphate (NADPH) oxidase and xanthine oxidase ${ }^{10}$. The main degradation pathway to reduce ROS levels employs superoxide dismutases [SODs; intracellular (SOD1), mitochondrial (SOD2), and extracellular (SOD3) isoforms], which metabolize $\mathrm{O}_{2}{ }^{\cdot-}$ to $\mathrm{H}_{2} \mathrm{O}_{2}{ }^{11} . \mathrm{H}_{2} \mathrm{O}_{2}$ is then processed to $\mathrm{O}_{2}$ and $\mathrm{H}_{2} \mathrm{O}$ by catalase or glutathione (GSH) peroxidase ${ }^{12}$. GSH is an important antioxidant peptide which can protect cells from toxic insults ${ }^{13}$. In addition, thioredoxin (Trx) is a small antioxidant protein $(\sim 12 \mathrm{kDa})$ that has redoxactive cysteine residues at its active site ${ }^{14}$. The oxidized form of Trx is reduced by NADPH-dependent Trx reductase (TrxR) ${ }^{14}$. While Trx1 and TrxR1 are usually localized in the cytoplasm, Trx2 and TrxR2 are found in mitochondria ${ }^{14}$. The Trx system is involved in cell survival, tumor development, and inflammatory diseases, particularly lung cancer ${ }^{15-18}$. Oxidative stress due to overproduction of ROS, a lack of antioxidants, or both, can lead to permanent modifications of proteins, lipids, and DNA, leading to cell death and tissue inflammation, consequently resulting in the chronic progression of many diseases including cancer ${ }^{19,20}$. More importantly, oxidative stress and chronic inflammation are associated with each other.

Tempol (4-hydroxy-2,2,6,6-tetramethylpiperidine-1-oxyl) is a synthetic cyclic nitroxide compound that has been commonly utilized as a contrast material in magnetic resonance spectroscopy ${ }^{21,22}$. It undergoes rapid reversible transfer between three forms: nitroxide, hydroxylamine and the oxoammonium cation form ${ }^{21}$. Therefore, Tempol is a potential redox agent that may function as a reductive or oxidative mediator depending on its concentration in the cell ${ }^{21}$. Treatment with Tempol removes a variety of ROS and diminishes oxidation, subsequently protecting cells and tissues from oxidative injuries ${ }^{23-27}$. Our previous reports have shown that Tempol prevents lung cancer cells and juxtaglomerular cells from undergoing cell death in response to cytotoxic insult ${ }^{28,29}$. Potential antioxidant mechanisms of Tempol have been proposed to explain these beneficial effects. One possibility is that it may act as a mimic of SOD and reduce the formation of ${ }^{\circ} \mathrm{OH}$ either by scavenging $\mathrm{O}_{2}{ }^{\cdot-}$ or by decreasing the intracellular concentration of $\mathrm{Fe}$ (II) ${ }^{23,24,30}$. However, increasing attention on Tempol in the clinical area has prompted more comprehensive studies on its potential toxicity. Abundant evidence suggests that Tempol interrupts ferritin synthesis and Fe metabolism, which could stimulate cell death ${ }^{31}$. The toxicity of Tempol is dosedependent and preferentially targets cancer cells ${ }^{32}$. It has been reported that Tempol at millimole concentrations inhibits cell growth and induces apoptosis, depending on cell types and origins ${ }^{32-34}$. Moreover, high concentrations of, or extended exposure to Tempol increases ROS levels in juxtaglomerular cells ${ }^{33}$, breast cancer cells ${ }^{35}$, and ovarian cancer cells ${ }^{34,36}$. Thus, in order to clarify the different effects of Tempol as pro-oxidant or antioxidant in cells and tissues, further in depth studies need to be undertaken to elucidate its biological mechanisms.

Recently, Tempol was shown to inhibit the growth of lung cancer and normal cells, and to induce apoptosis in these cells (unpublished data). However, little is known about mechanisms underlying antigrowth effects of Tempol in lung-related cells, with respect to cellular redox status i.e. ROS and GSH 
responses. Therefore, in this study, alterations to cellular redox molecules in response to Tempol were examined in A549 and Calu-6 lung cancer cells, as well as in primary normal human PF (HPF) cells and an SV40-transformed normal HPF line (WI-38 VA-13 subclone 2RA). Moreover, it was examined whether down-regulation of TrxR1 protein level affects cell growth and death as well as ROS levels in Tempoltreated lung cancer and normal cells.

\section{Materials And Methods \\ 2.1. Cell culture}

Human NSCLC A549 adenocarcinoma cells, SCLC Calu-6 cells, and normal lung WI-38 VA-13 subclone 2RA cells were obtained from the American Type Culture Collection (Manassas, VA, USA). Primary normal HPF cells were purchased from PromoCell GmbH (C-12360, Heidelberg, Germany) and used between passages five and ten. Lung cells were kept in a standard humidified incubator at $37^{\circ} \mathrm{C}$ with $5 \% \mathrm{CO}_{2}$ and cultured in RPMI-1640 medium supplemented with 10\% fetal bovine serum (FBS; Sigma-Aldrich Co., St. Louis, MO, USA) and 1\% penicillin-streptomycin (GIBCO BRL, Grand Island, NY, USA). Cells were grown in $100 \mathrm{~mm}$ plastic cell culture dishes (BD Falcon, Franklin Lakes, NJ, USA) and harvested with trypsin-EDTA (Gibco BRL).

\subsection{Reagents}

Tempol was obtained from Sigma-Aldrich Co. and dissolved in methanol (Sigma-Aldrich Co.) at $1 \mathrm{M}$ as a stock solution. 3-(4,5-dimethylthiazol-2-yl)-2,5-diphenyltetrazolium bromide (MTT) was also obtained from Sigma-Aldrich Co. and dissolved in distilled water. SOD and catalase proteins were acquired from Sigma-Aldrich Co. and dissolved in $50 \mathrm{mM}$ potassium phosphate buffer at $4733 \mathrm{U} / \mathrm{ml}$. Activity units of SOD and catalase were defined as the amount of enzyme needed to exhibit $50 \%$ dismutation of $\mathrm{O}_{2}{ }^{-{ }^{-}}$and to exhibit $50 \%$ decomposition of $\mathrm{H}_{2} \mathrm{O}_{2}$ to $\mathrm{O}_{2}$ and $\mathrm{H}_{2} \mathrm{O}$, respectively. TrxR1 protein was also acquired from Sigma-Aldrich Co. All stock solutions were wrapped in foil and kept at $4^{\circ} \mathrm{C}$ or $-20^{\circ} \mathrm{C}$. Methanol $(0.02 \%)$ was used as a vehicle control.

\subsection{Determination of intracellular ROS and $\mathrm{O}_{2}{ }^{--}$levels}

Overall levels of intracellular ROS including $\mathrm{H}_{2} \mathrm{O}_{2},{ }^{\circ} \mathrm{OH}$, and ONOO' were measured using a fluorescent probe dye, 2',7'-dichlorodihydrofluorescein diacetate $\left(\mathrm{H}_{2} \mathrm{DCFDA}\right.$, Ex/Em $=495 \mathrm{~nm} / 529 \mathrm{~nm}$; Invitrogen Molecular Probes, Eugene, OR, USA), as previously described ${ }^{37,38} . \mathrm{H}_{2}$ DCFDA is poorly sensitive to $\mathrm{O}_{2}{ }^{\cdot-}$. However, dihydroethidium (DHE, Ex/Em = 518nm/605nm; Invitrogen Molecular Probes) is a fluorogenic probe that interacts selectively with $\mathrm{O}_{2}{ }^{\cdot-37}$. In brief, $1 \times 10^{6}$ cells in $60 \mathrm{~mm}$ culture dishes (BD Falcon) were treated with Tempol at indicated concentrations $(0.5 \sim 4 \mathrm{mM})$ for $48 \mathrm{~h}$. Then, the cells were washed in phosphate-buffered saline (PBS; GIBCO BRL) and incubated with $20 \mu \mathrm{M} \mathrm{H}_{2}$ DCFDA or DHE at $37^{\circ} \mathrm{C}$ for 30 min. The mean DCF and DHE fluorescence values were analyzed using a FAC Star flow cytometer (BD Sciences). The mean DCF and DHE levels are expressed as percentages compared to control cells. 


\subsection{Western blot analysis}

Expression levels of various antioxidant proteins were evaluated via western blotting. Briefly, $5 \times 10^{6}$ cells in $100 \mathrm{~mm}$ culture dishes (BD Falcon) were incubated with the indicated concentrations of Tempol (0.5 $4 \mathrm{mM}$ ) for $48 \mathrm{~h}$. Cells were washed with PBS and four volumes of lysis buffer (Intron Biotechnology, Seongnam, Gyeonggi-do, Korea) were added. Total proteins $(30 \mu \mathrm{g})$ were resolved in $12.5 \%$ SDS-PAGE gels and then transferred to Immobilon-P PVDF membranes (Millipore, Billerica, MA, USA) by electroblotting. Membranes were probed with anti-SOD1, anti-catalase, anti-Trx1, anti-TrxR1, and anti- $\beta$ actin (Santa Cruz Biotechnology, Santa Cruz, CA, USA). Membranes were incubated with horseradish peroxidase-conjugated secondary antibodies (Santa Cruz Biotechnology). Western blots were developed using an EZ-Western Lumi Pico ECL solution kit (DoGen, Seoul, Korea).

\subsection{Measurement of cellular SOD activity}

The activity of cellular SOD enzyme was measured using an SOD assay kit (Sigma-Aldrich Co.), as previously described ${ }^{37}$. In brief, $1 \cdot 10^{6}$ cells in $60 \mathrm{~mm}$ culture dishes (BD Falcon) were incubated with 1 $\mathrm{mM}$ Tempol for $48 \mathrm{~h}$. Supernatant samples that contained $30 \mu \mathrm{g}$ protein were used for the measurement of SOD activity. These were added to wells of 96-well microtiter plates (Nunc, Roskilde, Denmark) with enzyme working solution containing a color reagent, and then the plates were incubated at $25^{\circ} \mathrm{C}$ for 10 min to produce a water-soluble formazan dye. Formazan crystal formation was measured at $450 \mathrm{~nm}$ using a microplate reader (Synergy ${ }^{\text {TW }} 2$, BioTekR Instruments Inc. Winooski, VT). SOD activity is expressed in arbitrary units.

\subsection{Measurement of cellular catalase activity}

The activity of cellular catalase was measured using a catalase assay kit from Sigma-Aldrich Co., as previously described ${ }^{37}$. In brief, $1 \cdot 10^{6}$ cells in $60 \mathrm{~mm}$ culture dishes (BD Falcon) were incubated with 1 $\mathrm{mM}$ Tempol for $48 \mathrm{~h}$. Supernatant samples containing $30 \mu \mathrm{g}$ protein were used for the determination of catalase activity. Samples were added to a microcentrifuge tube with assay buffer ( $50 \mathrm{mM} \mathrm{KH}_{2} \mathrm{PO}_{4} / 50$ $\mathrm{mM} \mathrm{Na}_{2} \mathrm{HPO}_{4}, \mathrm{pH} \mathrm{7.0)}$ and the reaction was commenced by the addition of $200 \mathrm{mM} \mathrm{H}_{2} \mathrm{O}_{2}$ solution at $25^{\circ} \mathrm{C}$ for $5 \mathrm{~min}$ and ended by addition of stop solution. One hundred $\mu \mathrm{l}$ of the above reaction mixture was removed and added to another microcentrifuge tube with the color reagent (150 mM potassium phosphate buffer, $\mathrm{pH7}$.0, containing $0.25 \mathrm{mM}$ 4-aminoantipyrine, $2 \mathrm{mM}$ 3,5-dichloro-2hydroxybenzenesulfonic acid, and the peroxidase solution), and was incubated at $25^{\circ} \mathrm{C}$ for $10 \mathrm{~min}$. The dye was measured at $520 \mathrm{~nm}$ using a microplate reader (Synergy ${ }^{\mathrm{TM}}$ 2). Catalase activity is expressed in arbitrary units.

\subsection{Measurement of cellular TrxR1 activity}

The activity of TrxR1 was assessed using a thioredoxin reductase assay kit according to the manufacturer's instructions (SigmaAldrich Co.). In brief, $1 \times 10^{6}$ cells in $60 \mathrm{~mm}$ culture dishes (BD Falcon) were incubated with $1 \mathrm{mM}$ Tempol for $48 \mathrm{~h}$. Supernatant samples containing $30 \mu \mathrm{g}$ protein were used for the determination of TrxR1 activity. These were added to wells of 96 well microtiter plates (Nunc) with 
$5,5^{\prime}$ dithiobis-(2nitrobenzoic acid) from the kit at $25^{\circ} \mathrm{C}$ for $1 \mathrm{~h}$. The optical density of each well was measured at $412 \mathrm{~nm}$ using a microplate reader (Synergy ${ }^{\mathrm{TM}} 2$ ). TrxR1 activity is expressed in arbitrary units.

\subsection{Transfection of cells with TrxR1 siRNAs}

Gene silencing of TrxR1 was performed as previously described ${ }^{39}$. A control scrambled siRNA duplex [5'CCUACGCCACCAAUUUCGU(dTdT)-3'] and TrxR1 siRNA duplex [5'-GUCGUCUAUGAGAAUGCUU(dTdT)-3'] were purchased from Bioneer Corp. (Daejeon, South Korea). In brief, $2 \cdot 10^{5}$ cells added to six-well plates (Nunc) were incubated in RPMI-1640 supplemented with 10\% FBS. The next day, cells (approximately 20 $\sim 30 \%$ confluence) in each well were transfected with the control, or TrxR1 siRNA duplex [80 pmol in OptiMEM (GIBCO BRL)] by means of LipofectAMINE 2000, according to the manufacturer's instructions (Invitrogen, Branford, CT). One day later, cells were treated with or without $1 \mathrm{mM}$ Tempol for $48 \mathrm{~h}$. The transfected cells were used for Western blotting, MTT assays, annexin V-fluorescein isothiocyanate (FITC, Life Technologies, Carlsbad, CA, USA; Ex/Em = 488/519 nm) staining, and ROS measurements.

\subsection{Cell growth inhibition assay}

The effects of Tempol on the growth of lung cells were determined using MTT assays. In brief, $1.5 \times 10^{4}$ cells per well were seeded in 96-well microtiter plates (Nunc) for MTT assays. After incubation with Tempol at $1 \mathrm{mM}$ for $48 \mathrm{~h}, 20 \mu \mathrm{L}$ of MTT solution ( $2 \mathrm{mg} / \mathrm{mL}$ in PBS) was added to each well. Plates were then incubated at $37^{\circ} \mathrm{C}$ for $3 \sim 4 \mathrm{~h}$. Medium in each well was removed by pipetting. Then $100 \sim 200 \mu \mathrm{L}$ of DMSO was added to each well to solubilize formazan crystals. Optical density was measured at $570 \mathrm{~nm}$ with a microplate reader (Synergy ${ }^{\text {TM }} 2$ ).

\subsection{Detection of apoptosis}

Apoptosis was identified via annexin V-FITC (Life Technologies) as previously described ${ }^{40}$. Briefly, $3 \times$ $10^{5} \sim 5 \times 10^{5}$ cells in six-well plates (Nunc) were incubated with Tempol at $1 \mathrm{mM}$ for $48 \mathrm{~h}$. Cells were washed twice with cold PBS and then suspended in $200 \mu \mathrm{L}$ of binding buffer $(10 \mathrm{mM} \mathrm{HEPES} / \mathrm{NaOH} \mathrm{pH}$ $7.4,140 \mathrm{mM} \mathrm{NaCl}, 2.5 \mathrm{mM} \mathrm{CaCl}$ ) at a density of $5 \times 10^{5}$ cells $/ \mathrm{mL}$ at $37^{\circ} \mathrm{C}$ for $30 \mathrm{~min}$. After adding Annexin V-FITC $(2 \mu \mathrm{L})$, cells were analyzed with a FAC Star flow cytometer (BD Sciences).

\subsection{Detection of intracellular GSH levels}

Cellular GSH levels were evaluated using fluorescent probe 5-chloromethylfluorescein diacetate (CMFDA, $\mathrm{Ex} / \mathrm{Em}=522 \mathrm{~nm} / 595 \mathrm{~nm}$; Invitrogen Molecular Probes), as previously described ${ }^{37}$. In brief, $1 \times 10^{6}$ cells in $60 \mathrm{~mm}$ culture dishes (BD Falcon) were treated with Tempol at indicated concentrations $(0.5 \sim 4 \mathrm{mM})$ for $48 \mathrm{~h}$. Then, the cells were washed with PBS and incubated with $5 \mu \mathrm{M} \mathrm{CMFDA}$ at $37^{\circ} \mathrm{C}$ for $30 \mathrm{~min}$. The mean CMF fluorescence intensity was determined using a FAC Star flow cytometer (BD Sciences). CMF negative (-) staining indicated the depletion of GSH content in cells. 


\subsection{Statistical analysis}

The results show the mean of more than two independent experiments (mean $\pm S D$ ). The data were analyzed using Instat software (GraphPad Prism 5.0, San Diego, CA, USA). A Student's $t$-test or one-way analysis of variance with post-hoc analysis using Tukey's multiple comparison test was applied to determine statistical significance, which was defined as $p$-values of $<0.05$.

\section{Results}

\subsection{Effect of Tempol on intracellular ROS levels in lung cancer and normal cells}

To assess the intracellular levels of different kinds of ROS in Tempol-treated cells, $\mathrm{H}_{2}$ DCFDA dye was used for general ROS levels and DHE dye was used for $\mathrm{O}_{2}{ }^{--}$levels. As shown in Fig. 1A, intracellular ROS (DCF) levels were significantly increased in A549 cells treated with $0.5 \sim 4 \mathrm{mM} \mathrm{Tempol}$ at $48 \mathrm{~h}$. Doses of 1 and $4 \mathrm{mM}$ Tempol increased the levels by about $170 \%$ and $200 \%$, respectively, compared with the control group. In contrast, all tested doses of Tempol significantly decreased ROS (DCF) levels in Calu-6 cells (Fig. 1B). Doses of 1 and $4 \mathrm{mM}$ Tempol decreased the levels by about $65 \%$ and $70 \%$, respectively (Fig. 2B). For the normal lung cells, Tempol at $0.5 \mathrm{mM}$ significantly decreased ROS (DCF) levels in WI-38 VA-13 cells at $48 \mathrm{~h}$ whereas 2 and $4 \mathrm{mM}$ Tempol significantly increased ROS (DCF) levels in these cells, with $4 \mathrm{mM}$ Tempol increasing the level by about $450 \%$ (Fig. 1C). While Tempol at 0.5 and $1 \mathrm{mM}$ significantly decreased ROS (DCF) levels in primary HPF cells at $48 \mathrm{~h}$ by about $50 \%, 2 \mathrm{mM}$ Tempol had no effect (Fig. 1D).

Intracellular $\mathrm{O}_{2}{ }^{--}$(DHE) levels were reduced in A549 cells treated with 0.5 and $1 \mathrm{mM}$ Tempol at $48 \mathrm{~h}$ but they were significantly increased at 2 and $4 \mathrm{mM}$, with $4 \mathrm{mM}$ Tempol increasing by about $500 \%$ (Fig. 2A). In Calu- 6 cells, all Tempol doses increased $\mathrm{O}_{2}{ }^{\cdot-}$ levels, with 1 and $4 \mathrm{mM}$ Tempol increasing it by about $130 \%$ and $430 \%$, respectively. In addition, Tempol at 2 and $4 \mathrm{mM}$ significantly increased $\mathrm{O}_{2}{ }^{-{ }^{-}}$levels in WI38 VA-13 cells by about $160 \%$ and $290 \%$, respectively (Fig. 2C). $\mathrm{O}_{2}{ }^{--}$levels were significantly increased in primary HPF cells treated with $0.5 \sim 2 \mathrm{mM}$ Tempol at $48 \mathrm{~h}$, with $2 \mathrm{mM}$ Tempol promoting a $220 \%$ increase (Fig. 2D).

\subsection{Effects of Tempol on the expression and activity of various antioxidant enzymes in lung cancer and normal cell cells}

Changing ROS levels result from alterations to antioxidant enzyme expression and activity. Thus, it was examined whether Tempol influenced the expression and activity of SOD, catalase, Trx1, and TrxR1 in lung cancer and normal cells at $48 \mathrm{~h}$. As shown in Figs. $3 \mathrm{~A}$ and B, Tempol at $0.5 \sim 2 \mathrm{mM}$ did not affect 
SOD1 protein levels in A549 cells but increased the levels in Calu- 6 cells. While $0.5 \mathrm{mM}$ and $1 \mathrm{mM}$ doses of Tempol diminished SOD1 protein levels in WI-38 VA-13 cells, $2 \mathrm{mM}$ slightly increased the protein level (Fig. 3C). For catalase, apparent differences in expression levels were not detected in Tempol-treated A549 and WI-38 VA-13 cells (Figs. 3 A and C) while in contrast it down-regulated catalase in Calu- 6 cells (Fig. 3B). In addition, Tempol increased Trx1 protein expression in A549 cells and WI-38 VA-13 cells (Figs. 3A and C) but did not affect Trx1 in Calu-6 (Fig. 3B). Meanwhile increases in TrxR1 protein levels in response to Tempol were observed in all of these lung cells (Fig. 3 ).

Regarding the activity of these enzymes, it was found that the activity of SOD was down-regulated in A549 cells treated with $1 \mathrm{mM}$ Tempol at $48 \mathrm{~h}$ while it was up-reregulated in $1 \mathrm{mM}$ Tempol-treated Calu-6 cells (Fig. 4A). At $1 \mathrm{mM}$ it did not affect the activity of SOD in WI-38 VA-13 cells (Fig. 4A). In addition, the activity of catalase was enhanced in Tempol-treated A549 and Calu- 6 cells whereas it was significantly decreased in WI-38 VA-13 cells (Fig. 4B). Moreover, 1 mM Tempol significantly decreased the activity of TrxR1 at $48 \mathrm{~h}$ in all of these lung cells as compared to control cells (Fig. 4).

\subsection{Effects of Trx1R1 silencing on cell growth, cell death, and ROS levels in Tempol-treated lung cancer and normal cells}

Because treatment with Tempol dose-dependently increased TrxR1 protein levels in A549, Calu-6, and Wi38 VA-13 cells at $48 \mathrm{~h}$ (Fig. 3), it was assumed that changes in TrxR1 were closely related to cell growth and death as well as ROS levels. Hence whether gene silencing of TrxR1 using siRNA knock-down alters these cellular effects was examined. TrxR1 siRNA knock-down efficiently decreased protein levels more than $90 \%$ in all cell types at $48 \mathrm{~h}$, as compared to scramble siRNA-transfected cells (Fig. 5A). Transfection of TrxR1 siRNA decreased the growth of A549 cells at $48 \mathrm{~h}$ by about $20 \%$ compared with control transfected A549 cells whereas cell growth was unaffected in Calu- 6 and Wi-38 VA-13 cells (Fig. 5B). Treatment with $1 \mathrm{mM}$ Tempol decreased the growth of scramble siRNA-transfected A549, Calu-6, and Wi38 VA- 13 cells by about 55\%, 50\%, and 55\%, respectively (Fig. 5B). Tempol at $1 \mathrm{mM}$ also reduced the growth of TrxR1 siRNA-transfected A549, Calu-6, and Wi-38 VA-13 cells by about $50 \%, 40 \%$, and $50 \%$, respectively (Fig. 5B).

In relation to cell death, transfection with TrxR1 siRNA did not significantly alter the proportion of annexin V-positive cells in untreated A549, Calu-6, and Wi-38 VA-13 cells at $48 \mathrm{~h}$ (Fig. 6A). However Tempol at 1 $\mathrm{mM}$ significantly increased the amounts of annexin V-positive cells in both scramble siRNA- and TrxR1 siRNA-transfected A549 cells by approximately $30 \%$ and $27 \%$, respectively (Fig. 6A). In addition, Tempol increased the amounts of annexin V-positive cells in scramble siRNA- and TrxR1 siRNA-transfected Calu- 6 cells by approximately $24 \%$ (Fig. 6A). Interestingly, it augmented the proportion of annexin V-positive cells in scramble siRNA- and TrxR1 siRNA-transfected Wi-38 VA-13 cells by approximately $22 \%$ and $17 \%$, respectively, implying that knock-down of TrxR1 attenuates cell death in Tempol-treated Wi-38 VA-13 cells (Fig. 6A). With respect to ROS levels, TrxR1 silencing slightly decreased ROS levels in A549 cells at $48 \mathrm{~h}$ 
and slightly increased ROS levels in Calu-6 cells (Fig. 6B). Tempol at $1 \mathrm{mM}$ significantly increased ROS levels in scramble siRNA- and TrxR1 siRNA-transfected A549 cells at $48 \mathrm{~h}$ by approximately $175 \%$ and 130\%, respectively (Fig. 6B). In contrast, $1 \mathrm{mM}$ Tempol decreased ROS levels in scramble and TrxR1 siRNA-transfected Calu- 6 cells by approximately $40 \%$ and $15 \%$, respectively (Fig. 6B), while in Wi-38 VA-13 cells, it did not significantly change ROS levels (Fig. 6B).

\subsection{Effect of Tempol on GSH levels in lung cancer and normal cells}

Changes in GSH levels were assessed in lung-related cells using CMF fluorescent dye. As shown in Fig. 7A, Tempol at 0.5 and $1 \mathrm{mM}$ did not augment the number of GSH-depleted cells in Calu- 6 cells at 48 $\mathrm{h}$, whereas 2 and $4 \mathrm{mM}$ concentrations significantly increased the number of GSH-depleted cells by about $44 \%$ and $74 \%$, respectively. Tempol at $0.5 \sim 4 \mathrm{mM}$ significantly increased the number of GSH-depleted cells in A549 cells at $48 \mathrm{~h}$, with 1 and $4 \mathrm{mM}$ Tempol increasing numbers by about $20 \%$ and $60 \%$, respectively (Fig. 7B). In WI-38 VA-13 cells, 0.5 and $1 \mathrm{mM}$ Tempol did not affect the number of GSHdepleted cells but 2 and $4 \mathrm{mM}$ concentrations significantly augmented the number of GSH-depleted cells by about $28 \%$ and $90 \%$, respectively (Fig. 7 C).

\section{Discussion}

Tempol has been shown to protect cells and tissues from oxidative damage ${ }^{23-27}$. In contrast, it has also been reported that Tempol enhances inflammation and oxidative damage in numerous cell and tissue models ${ }^{21,24}$. According to our unpublished data, Tempol at $0.5 \sim 4 \mathrm{mM}$ inhibits the growth of lung cancer and normal cells with an $\mathrm{IC}_{50}$ of approximately $1 \sim 2 \mathrm{mM}$ at $48 \mathrm{~h}$, and induces apoptosis in these cells. Thus, the current study has focused on investigating changes in cellular redox status and antioxidant enzymes in Tempol-treated lung cancer and normal cells.

It is reported that millimole concentrations of Tempol or extended exposure to it increases ROS levels in juxtaglomerular cells ${ }^{33}$, breast cancer cells ${ }^{35}$, and ovarian cancer cells ${ }^{34,36}$. Results from the present study showed that ROS (DCF) levels were significantly increased in A549 cells treated with $0.5 \sim 4 \mathrm{mM}$ Tempol and in WI-38 VA-13 cells treated with 2 and 4 mM Tempol. However, ROS (DCF) were significantly reduced in Calu- 6 cells treated with $0.5 \sim 4$ mM Tempol and in WI-38 VA-13 cells treated with $0.5 \mathrm{mM}$ Tempol. In addition, Tempol at 0.5 and $1 \mathrm{mM}$ significantly decreased ROS (DCF) in primary HPF cells. These results imply that Tempol can raise or lower ROS (DCF) levels depending on the cell type without significant differences between lung cancer and normal lung cells. Tempol at $1 \mathrm{mM}$ significantly increased the activity of catalase in Calu- 6 cells, possibly resulting in a decrease in intracellular $\mathrm{H}_{2} \mathrm{O}_{2}$ level due to the high conversion from $\mathrm{H}_{2} \mathrm{O}_{2}$ to $\mathrm{O}_{2}$ and $\mathrm{H}_{2} \mathrm{O}$. However, the increased activity of catalase in Tempol-treated A549 cells did not reduce ROS (DCF) levels and the decreased activity of catalase in Tempol-treated WI-38 VA-13 cells did not increase ROS (DCF). In addition, Tempol did not apparently alter the expression of catalase in A549 and WI-38 VA-13 cells and decreased catalase in Calu-6 cells. 
Therefore, the expression levels of catalase in lung cancer and normal cells did not correlate with its enzymatic activity.

Intracellular $\mathrm{O}_{2}{ }^{--}$(DHE) levels were increased in A549, Calu-6, WI-38 VA-13, and primary HPF cells treated with 2 or $4 \mathrm{mM}$ Tempol. Tempol also increased $\mathrm{O}_{2}{ }^{\cdot-}$ levels in Calu- 6 and primary HPF cells at 0.5 and 1 $\mathrm{mM}$ but these doses did not augment $\mathrm{O}_{2}{ }^{\cdot-}$ levels in A549 and WI-38 VA-13 cells. Relatively high concentrations of Tempol appeared to increase $\mathrm{O}_{2}{ }^{--}$in each of the cell lines. Tempol is a mimic of SOD which metabolizes $\mathrm{O}_{2}{ }^{--}$to $\mathrm{H}_{2} \mathrm{O}_{2}{ }^{23,30}$. Similarly, $1 \mathrm{mM}$ Tempol up-regulated the activity of SOD in Calu- 6 cells at $48 \mathrm{~h}$. However, Tempol did not affect the activity of SOD in WI-38 VA-13 cells. Tempol at $1 \mathrm{mM}$ even reduced the activity of SOD in A549 cells. Treatment with Tempol increased SOD1 protein levels in Calu- 6 cells but not in A549 cells. Contrastingly, at 1 mM it decreased the levels in WI-38 VA-13 cells. Therefore, the expression levels of SOD1 in A549 and WI-38 VA-13 cells were not related to its enzymatic activity. It was speculated that the increased amount of intracellular $\mathrm{O}_{2}{ }^{-{ }^{-}}$in cells in response to Tempol may have been originated from mitochondria. Numerous reports have demonstrated that Tempol mediates its toxicity via the disruption of mitochondrial function $33,34,41$, suggesting that Tempols effects on mitochondria may result in excessive production of $\mathrm{O}_{2}{ }^{\cdot-}$, causing oxidative stress and consequently apoptosis. In fact, 2 and $4 \mathrm{mM}$ of Tempol strongly increased mitochondrial $\mathrm{O}_{2}{ }^{\cdot-}$ levels (as determined by MitoSOX ${ }^{\mathrm{TM}}$ Red agent) in WI-38 VA-13 cells at $48 \mathrm{~h}$, by approximately 6 -fold and 22 -fold, respectively (data not shown). In lung cancer and normal cells, death from Tempol was more correlated with changes in $\mathrm{O}_{2}{ }^{\cdot-}$ levels than ROS (DCF) levels. The apparently paradoxical effects of Tempol in different conditions and different cells may be explained by assuming that each cell has a different basal activity of mitochondria and a variety of antioxidant enzymes.

The Trx system consists of Trx, TrxR, and NADPH and is a fundamental enzymatic complex that preserves cellular redox homeostasis ${ }^{14}$. Trx 1 and/or TrxR1 are overexpressed in various pulmonary diseases including cancer ${ }^{16,42-44}$. Hence, it is plausible that the Trx system is a promising target for treatment of lung cancer. Tempol at $1 \mathrm{mM}$ significantly decreased the activity of TrxR1 in A549, Calu-6, and Wi-38 VA-13 cells. However, TrxR1 protein levels were increased in all these lung cells. Thus, the increased activity of TrxR1 in Tempol-treated lung cells is more likely to be attributed to other factors such as Trx and Trx-interacting proteins rather than simple expression levels. In addition, Tempol treatment increased Trx 1 protein expression in A549 cells and WI-38 VA-13 cells but not in Calu- 6 cells. Further research is needed on the mechanism underlying alterations in the Tempol-mediated Trx system.

Treatment of Tempol at $1 \sim 5 \mathrm{mM}$ inhibits cell growth and induces apoptosis in various cancer cells ${ }^{33-}$ $36,41,45$. Likewise, $1 \mathrm{mM}$ Tempol reduced the growth of scramble siRNA-transfected A549 and Calu- 6 lung cancer cells, and Wi-38 VA-13 normal cells by about $55 \%, 50 \%$, and $55 \%$ at $48 \mathrm{~h}$, respectively. Moreover, Tempol at $1 \mathrm{mM}$ also significantly increased the amounts of annexin V-positive cells in scramble siRNAtransfected A549, Calu- 6 , and Wi-38 VA-13 cells by about $30 \%, 24 \%$, and $22 \%$ at 48 h, respectively. Therefore, Tempol is likely to induce lung cell death via apoptosis and/or necrosis. There was no 
significant difference in the susceptibility to Tempol among these lung cancer and normal cells. TrxR1 silencing itself did not influence the growth of Calu- 6 and Wi-38 VA-13 cells compared with scramble siRNA-transfected control cells but it did inhibit the growth of A549 control cells by about $20 \%$.

Transfection of TrxR1 siRNA did not significantly alter the growth rates of Tempol-treated lung cancer and normal cells. Thus, decreased TrxR1 protein level was involved in growth inhibition of A549 cells and did not affect growth changes in response to Tempol in these lung cells. In addition, TrxR1 siRNA alone did not increase the amounts of annexin V-positive cells in A549, Calu-6, and Wi-38 VA-13 control cells. Furthermore, knock-down of TrxR1 slightly decreased cell death in Tempol-treated A549 cells and significantly attenuated cell death in Tempol-treated Wi-38 VA-13 cells. These results suggest that downregulated TrxR1 levels are not closely related to cell survival in Tempol-naive lung cells but in part to cell survival in Tempol-treated cells.

A549 cells transfected with TrxR1 siRNA showed slightly decreased ROS (DCF) levels at $48 \mathrm{~h}$ while transfected Calu- 6 cells showed slight increases. TrxR1 siRNA reduced the increased levels of ROS (DCF) in Tempol-treated A549 cells whereas silencing partially recovered the decreased levels of ROS (DCF) in Tempol-treated Calu-6 cells. In Wi-38 VA-13 cells, TrxR1 siRNA did not alter ROS (DCF) levels regardless of $1 \mathrm{mM}$ Tempol treatment. It has been reported that Trx or TrxR1 could regulate the basal cellular metabolism of glycolysis, tricarboxylic acid cycle, and mitochondria to produce adenosine triphosphate (ATP) or $\mathrm{NAD}(\mathrm{P}) \mathrm{H}^{46}$. In addition, there are potentially harmful interactions between Tempol and enzyme complexes, which are inolved in glucose transport, glutamine metabolism and mitochondiral ATP production ${ }^{21,24,34}$. Therefore, further studies are needed on the difference in cellular ROS levels in lung cancer and normal cells following downregulation of TrxR1 and treatment with Tempol.

Depletion of GSH promotes cell death ${ }^{47-49}$ and this has been reported to occur in Tempol-treated leukemia and cervical cancer cells ${ }^{41,50}$. Similarly, the present study demonstrated an increased proportion of GSH-depleted cells in A549, Calu-6, and Wi-38 VA-13 cells treated with 2 and $4 \mathrm{mM}$ Tempol. Lower doses of Tempol ( 0.5 and $1 \mathrm{mM})$ induced fewer GSH-depleted cells in Calu- 6 cells. These results support the notion that the induction of cell death was inversely proportional to GSH content ${ }^{47-49}$. However, $1 \mathrm{mM}$ Tempol, which showed cell growth inhibition and cell death in A549 and WI-38 VA-13 cells, did not significantly augment the number of GSH-depleted cells in these cells. GSH content is a crucial factor or indicator of cell death induced by Tempol, but its concentration alone is not sufficient to accurately predict cell death.

In summary, the present results have shown that Tempol at $0.5 \sim 4 \mathrm{mM}$ could either increase or decrease ROS (DCF) levels in lung cancer and normal cells and this drug specifically increased $\mathrm{O}_{2}{ }^{-{ }^{-}}$levels and GSH depletion. Tempol at $1 \mathrm{mM}$ inhibited the growth of lung cancer and normal cells and also induced their cell death. There was no significant difference in Tempol sensitivity between lung cancer and normal cells. In addition, Tempol had other effects on the expression and activity of antioxidant enzymes, especially TrxR1 in lung cancer and normal cells. Furthermore, down-regulation of TrxR1 partially affected cell growth and death as well as ROS (DCF) levels in both Tempol-untreated or -treated cells, depending 
on the cell type. The current results provide valuable information for understanding the cellular effects of Tempol on lung cancer and normal cells with regard to cell growth inhibition and cell death, as well as redox states (ROS and GSH levels) and various antioxidant pathways.

\section{Abbreviations}

NSCLC, non-small cell lung cancer; SCLC, small cell lung cancer; HPF, human pulmonary fibroblast; ROS, reactive oxygen species; GSH, glutathione, Trx, thioredoxin; TrxR, Trx reductase; SOD, superoxide dismutase; NADPH, Nicotinamide adenine dinucleotide phosphate; $\mathrm{H}_{2}$ DCFDA, 2',7'-

dichlorodihydrofluorescein diacetate; DHE, dihydroethidium; CMFDA, 5-chloromethylfluorescein diacetate; MTT, 3-(4,5-dimethylthiazol-2-yl)-2,5-diphenyltetrazolium bromide; FITC, fluorescein isothiocyanate

\section{Declarations}

\section{Acknowledgments}

The present study was supported by a grant (2019R1I1A2A01041209) of the Basic Science Research Program through the National Research Foundation of Korea (NRF) funded by the Ministry of Education, Republic of Korea.

\section{Ethics declarations}

The material in this paper has not been published or is not under active consideration by another journal. The research was conducted in accordance with the declaration of Helsinki.

\section{Conflicts of interest statement}

None declared

\section{Declaration of interests}

The authors declare that they have no known competing financial interests or personal relationships that could have appeared to influence the work reported in this paper.

\section{Author Contribution}

Woo-Hyun Park is the only author who planned and conducted all experiments and wrote the present paper. 


\section{Availability of data and materials}

Data collected during the present study are available from the corresponding author upon reasonable request.

\section{Patient consent for publication}

Not applicable

\section{References}

1. Hinz, B. et al. Recent developments in myofibroblast biology: paradigms for connective tissue remodeling. Am J Patho/180, 1340-1355, doi:S0002-9440(12)00098-3

[pii]10.1016/j.ajpath.2012.02.004.

2. Wilson, M. S. \& Wynn, T. A. Pulmonary fibrosis: pathogenesis, etiology and regulation. Mucosal Immuno/2, 103-121, doi:10.1038/mi.2008.85 (2009).

3. Hu, Z. et al. Advances in clinical trials of targeted therapy and immunotherapy of lung cancer in 2018. Trans/ Lung Cancer Res8, 1091-1106, doi:10.21037/tlcr.2019.10.17 (2019).

4. Salehi-Rad, R., Li, R., Paul, M. K., Dubinett, S. M. \& Liu, B. The Biology of Lung Cancer: Development of More Effective Methods for Prevention, Diagnosis, and Treatment. Clin Chest Med41, 25-38, doi:10.1016/j.ccm.2019.10.003 (2020).

5. Huska, J. D., Lamb, H. M. \& Hardwick, J. M. Overview of BCL-2 Family Proteins and Therapeutic Potentials. Methods Mol Bio/1877, 1-21, doi:10.1007/978-1-4939-8861-7_1 (2019).

6. Chung, C. Restoring the switch for cancer cell death: Targeting the apoptosis signaling pathway. Am $J$ Health Syst Pharm75, 945-952, doi:10.2146/ajhp170607 (2018).

7. Petty, R. D., Nicolson, M. C., Kerr, K. M., Collie-Duguid, E. \& Murray, G. I. Gene expression profiling in non-small cell lung cancer: from molecular mechanisms to clinical application. Clin Cancer Res10, 3237-3248 (2004).

8. Gonzalez, C. et al. Significance of ROS in oxygen sensing in cell systems with sensitivity to physiological hypoxia. Respir Physiol Neurobio/132, 17-41 (2002).

9. Baran, C. P., Zeigler, M. M., Tridandapani, S. \& Marsh, C. B. The role of ROS and RNS in regulating life and death of blood monocytes. Curr Pharm Des10, 855-866 (2004).

10. Zorov, D. B., Juhaszova, M. \& Sollott, S. J. Mitochondrial ROS-induced ROS release: An update and review. Biochim Biophys Acta1757, 509-517 (2006).

11. Zelko, I. N., Mariani, T. J. \& Folz, R. J. Superoxide dismutase multigene family: a comparison of the CuZn-SOD (SOD1), Mn-SOD (SOD2), and EC-SOD (SOD3) gene structures, evolution, and expression. Free Radic Biol Med33, 337-349 (2002). 
12. Wilcox, C. S. Reactive oxygen species: roles in blood pressure and kidney function. Curr Hypertens Rep4, 160-166 (2002).

13. Lauterburg, B. H. Analgesics and glutathione. American journal of therapeutics9, 225-233 (2002).

14. Collet, J. F. \& Messens, J. Structure, function, and mechanism of thioredoxin proteins. Antioxidants \& redox signaling13, 1205-1216, doi:10.1089/ars.2010.3114 (2010).

15. Tipple, T. E. The thioredoxin system in neonatal lung disease. Antioxid Redox Signa/21, 1916-1925, doi:10.1089/ars.2013.5782 (2014).

16. Xu, J., Li, T., Wu, H. \& Xu, T. Role of thioredoxin in lung disease. Pulm Pharmacol Ther25, 154-162, doi:10.1016/j.pupt.2012.01.002 (2012).

17. Nakamura, T. et al. Redox regulation of lung inflammation by thioredoxin. Antioxid Redox Signal, 60-71, doi:10.1089/ars.2005.7.60 (2005).

18. Pramanik, K. C. \& Srivastava, S. K. Apoptosis signal-regulating kinase 1-thioredoxin complex dissociation by capsaicin causes pancreatic tumor growth suppression by inducing apoptosis. Antioxidants \& redox signaling17, 1417-1432, doi:10.1089/ars.2011.4369 (2012).

19. Vassalle, C., Maltinti, M. \& Sabatino, L. Targeting Oxidative Stress for Disease Prevention and Therapy: Where Do We Stand, and Where Do We Go from Here. Molecules25, 2653, doi:10.3390/molecules25112653 (2020).

20. Hayes, J. D., Dinkova-Kostova, A. T. \& Tew, K. D. Oxidative Stress in Cancer. Cancer Cel/38, 167-197, doi:10.1016/j.ccell.2020.06.001 (2020).

21. Wilcox, C. S. Effects of tempol and redox-cycling nitroxides in models of oxidative stress. Pharmacol Ther126, 119-145, doi:10.1016/j.pharmthera.2010.01.003 (2010).

22. Samuni, A., Krishna, C. M., Mitchell, J. B., Collins, C. R. \& Russo, A. Superoxide reaction with nitroxides. Free Radic. Res. Commun.9, 241-249 (1990).

23. Wilcox, C. S. Effects of tempol and redox-cycling nitroxides in models of oxidative stress. Pharmacol. Ther.126, 119-145, doi:S0163-7258(10)00009-4 [pii]10.1016/j.pharmthera.2010.01.003 (2010).

24. Augusto, O., Trindade, D. F., Linares, E. \& Vaz, S. M. Cyclic nitroxides inhibit the toxicity of nitric oxidederived oxidants: mechanisms and implications. An Acad Bras Cienc80, 179-189, doi:10.1590/s0001-37652008000100013 (2008).

25. Silva, D. A. D. et al. Tempol reduces inflammation and oxidative damage in cigarette smoke-exposed mice by decreasing neutrophil infiltration and activating the Nrf2 pathway. Chem Biol Interact329, 109210, doi:10.1016/j.cbi.2020.109210 (2020).

26. Crupi, R. et al. Effect of Tempol, a Membrane-Permeable Free Radical Scavenger, on In Vitro Model of Eye Inflammation on Rabbit Corneal Cells. J Ocul Pharmacol Ther35, 571-577, doi:10.1089/jop.2019.0016 (2019).

27. Wang, Y. et al. Tempol alleviates chronic intermittent hypoxia-induced pancreatic injury through repressing inflammation and apoptosis. Physiol Res68, 445-455, doi:10.33549/physiolres. 934010 (2019). 
28. Han, Y. H., Kim, S. Z., Kim, S. H. \& Park, W. H. Apoptosis in pyrogallol-treated Calu-6 cells is correlated with the changes of intracellular GSH levels rather than ROS levels. Lung Cancer59, 301-314, doi:10.1016/j.lungcan.2007.08.034 (2008).

29. Park, W. H., Han, Y. W., Kim, S. H. \& Kim, S. Z. A superoxide anion generator, pyrogallol induces apoptosis in As4.1 cells through the depletion of intracellular GSH content. Mutat Res619, 81-92, doi:10.1016/j.mrfmmm.2007.02.004 (2007).

30. Mitchell, J. B. et al. Biologically active metal-independent superoxide dismutase mimics. Biochemistry29, 2802-2807 (1990).

31. Goralska, M., Holley, B. \& McGahan, M. C. The effects of Tempol on ferritin synthesis and Fe metabolism in lens epithelial cells. Biochim. Biophys. Acta1497, 51-60, doi:S0167-4889(00)00038-0 [pii] (2000).

32. Gariboldi, M. B. et al. Antiproliferative effect of the piperidine nitroxide TEMPOL on neoplastic and nonneoplastic mammalian cell lines. Free Radic. Biol. Med.24, 913-923, doi:S0891-5849(97)00372-9 [pii] (1998).

33. Han, Y. H. \& Park, W. H. Tempol inhibits growth of As4.1 juxtaglomerular cells via cell cycle arrest and apoptosis. Oncology reports27, 842-848, doi:10.3892/or.2011.1518 (2012).

34. Ye, S. et al. The heterocyclic compound Tempol inhibits the growth of cancer cells by interfering with glutamine metabolism. Cell Death Dis11, 312, doi:10.1038/s41419-020-2499-8 (2020).

35. Gariboldi, M. B. et al. Antiproliferative effect of the piperidine nitroxide TEMPOL on neoplastic and nonneoplastic mammalian cell lines. Free Radic Biol Med24, 913-923, doi:10.1016/s08915849(97)00372-9 (1998).

36. Wang, M. et al. Piperidine nitroxide Tempol enhances cisplatin-induced apoptosis in ovarian cancer cells. Oncology letters16, 4847-4854, doi:10.3892/ol.2018.9289 (2018).

37. Han, Y. H. \& Park, W. H. Propyl gallate inhibits the growth of HeLa cells via regulating intracellular GSH level. Food and chemical toxicology : an international journal published for the British Industrial Biological Research Association47, 2531-2538, doi:10.1016/j.fct.2009.07.013 (2009).

38. Park, W. H. Upregulation of thioredoxin and its reductase attenuates arsenic trioxideinduced growth suppression in human pulmonary artery smooth muscle cells by reducing oxidative stress. Oncology reports43, 358-367, doi:10.3892/or.2019.7414 (2020).

39. You, B. R. \& Park, W. H. Down-Regulation of Thioredoxin1 Is Involved in Death of Calu-6 Lung Cancer Cells Treated With Suberoyl Bishydroxamic Acid. J Cell Biochem117, 1250-1261, doi:10.1002/jcb.25409 (2016).

40. Park, W. H. Hydrogen peroxide inhibits the growth of lung cancer cells via the induction of cell death and G1phase arrest. Oncology reports40, 1787-1794, doi:10.3892/or.2018.6535 (2018).

41. Monti, E. et al. Nitroxide TEMPOL impairs mitochondrial function and induces apoptosis in HL60 cells. J Cell Biochem82, 271-276, doi:10.1002/jcb.1160 (2001).

42. Fernandes, A. P. et al. Expression profiles of thioredoxin family proteins in human lung cancer tissue: correlation with proliferation and differentiation. Histopathology55, 313-320, doi:10.1111/j.1365- 
2559.2009.03381.x (2009).

43. You, B. R. \& Park, W. H. Suberoylanilide hydroxamic acid induces thioredoxin1-mediated apoptosis in lung cancer cells via up-regulation of miR-129-5p. Mol Carcinog56, 2566-2577, doi:10.1002/mc.22701 (2017).

44. Sugiura, H. \& Ichinose, M. Oxidative and nitrative stress in bronchial asthma. Antioxid Redox Signa/10, 785-797, doi:10.1089/ars.2007.1937 (2008).

45. Suy, S., Mitchell, J. B., Samuni, A., Mueller, S. \& Kasid, U. Nitroxide tempo, a small molecule, induces apoptosis in prostate carcinoma cells and suppresses tumor growth in athymic mice. Cancer103, 1302-1313, doi:10.1002/cncr.20898 (2005).

46. Daloso, D. M. et al. Thioredoxin, a master regulator of the tricarboxylic acid cycle in plant mitochondria. Proc Natl Acad Sci U S A112, E1392-1400, doi:10.1073/pnas.1424840112 (2015).

47. Han, Y. H., Kim, S. Z., Kim, S. H. \& Park, W. H. Induction of apoptosis in arsenic trioxide-treated lung cancer A549 cells by buthionine sulfoximine. Mol Cells26, 158-164, doi:107 [pii] (2008).

48. Park, W. H., Han, B. R., Park, H. K. \& Kim, S. Z. Arsenic trioxide induces growth inhibition and death in human pulmonary artery smooth muscle cells accompanied by mitochondrial $02^{*}$ - increase and GSH depletion. Environ Toxicol, doi:10.1002/tox.22569 (2018).

49. You, B. R. \& Park, W. H. Auranofin induces mesothelioma cell death through oxidative stress and GSH depletion. Oncology reports35, 546-551, doi:10.3892/or.2015.4382 (2016).

50. Han, Y. H., Kim, S. Z., Kim, S. H. \& Park, W. H. Suppression of arsenic trioxide-induced apoptosis in HeLa cells by N-acetylcysteine. Molecules and cells26, 18-25 (2008).

\section{Figures}




\section{Figure 1}

A

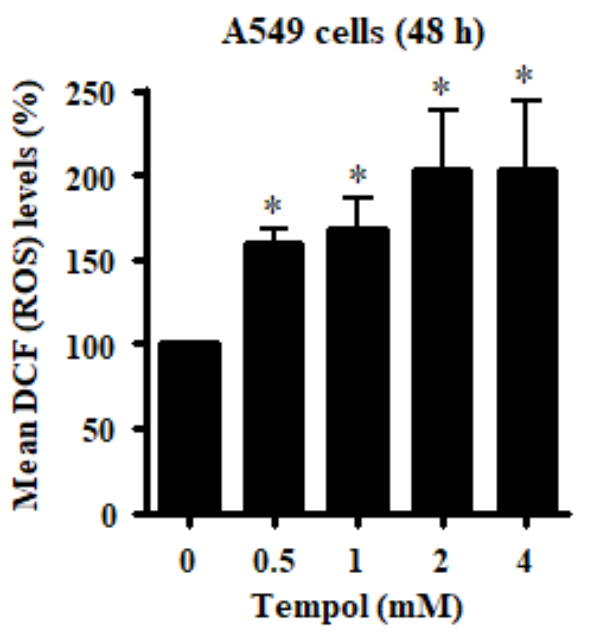

C

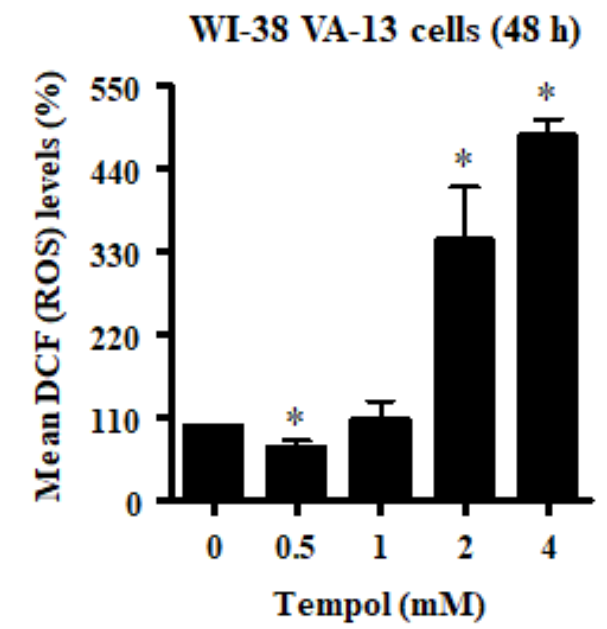

B

Calu- 6 cells $(48$ h)

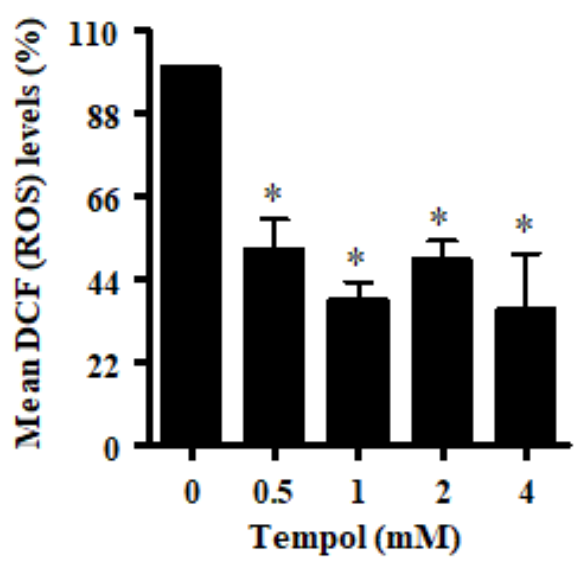

D Primary HPF cells $(48$ h)

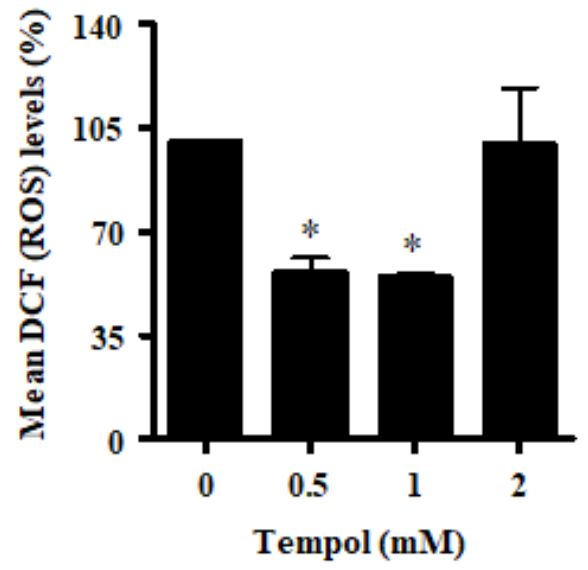

Figure 1

Effects of Tempol on intracellular ROS (DCF) levels in lung cancer and normal cells. Cells in the exponential growth phase were incubated with the indicated concentrations of Tempol for $48 \mathrm{~h}$. Intracellular ROS (DCF) levels in lung cells were measured using a FAC Star flow cytometer. The graphs indicate mean ROS (DCF) levels (\%) in A549 cells (A), Calu-6 cells (B), WI-38 VA-13 cells (C), and primary HPF cells (D). ${ }^{\star} p<0.05$ compared with untreated controls. 
Figure 2

$\mathbf{A}$

A549 cells (48 h)

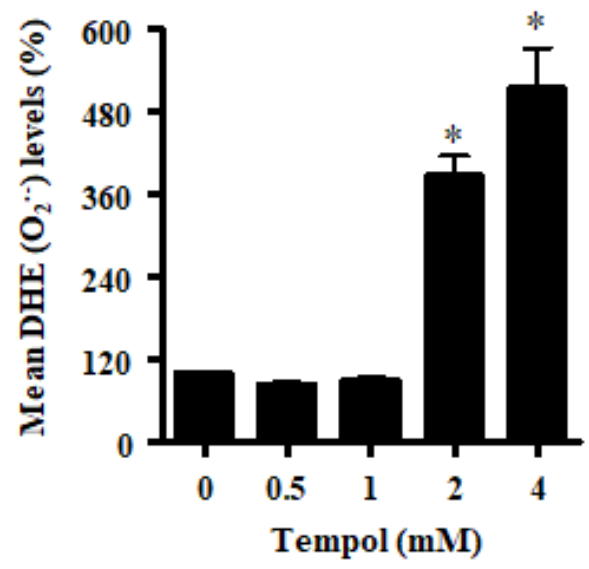

C

WI-38 VA-13 cells ( 48 h)

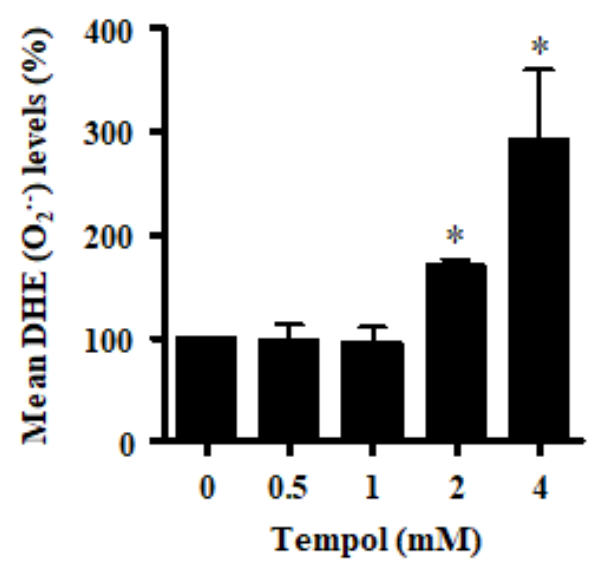

B

Calu- 6 cells $(48$ h)

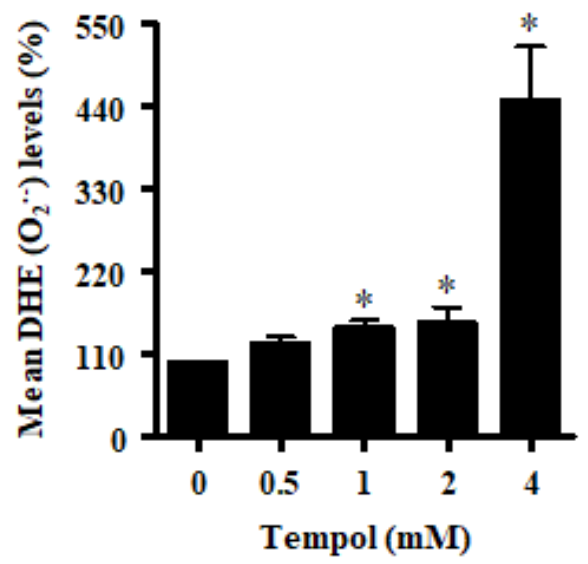

D Primary HPF cells $(48$ h)

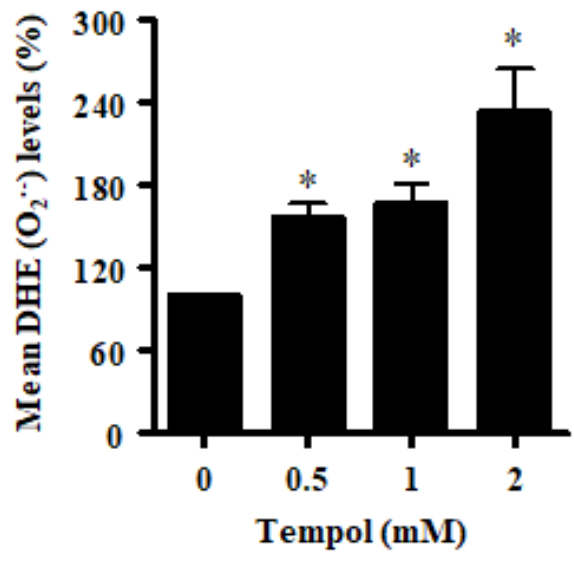

Figure 2

Effects of Tempol on intracellular DHE (02--) levels in lung cancer and normal cells. Cells in the exponential growth phase were incubated with the indicated concentrations of Tempol for $48 \mathrm{~h}$. Intracellular DHE (02--) levels in lung cells were measured using a FAC Star flow cytometer. The graphs indicate mean DHE (02--) levels (\%) in A549 cells (A), Calu-6 cells (B), WI-38 VA-13 cells (C), and primary HPF cells (D). ${ }^{*} p<0.05$ compared with untreated controls. 


\section{Figure 3}

$\mathbf{A}$

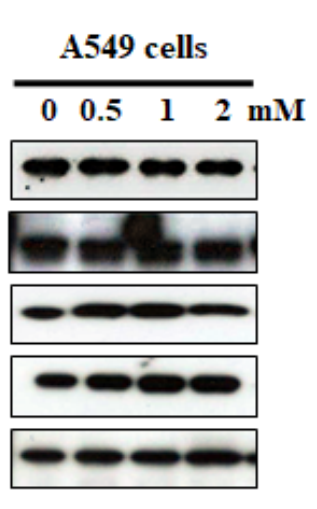

B

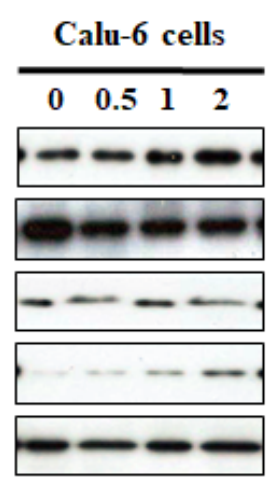

C

WI-38 VA-13 cells

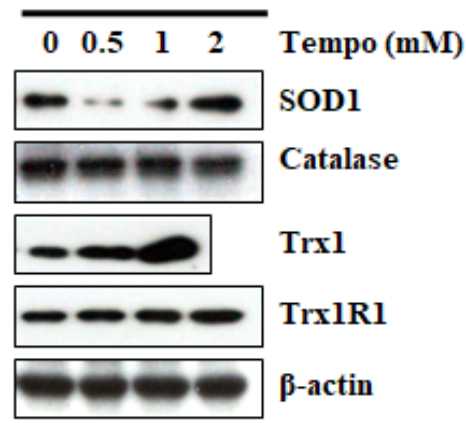

\section{Figure 3}

Effects of Tempol on the expression levels of SOD1, catalase, Trx1, and TrxR1 in lung cancer and normal cell cells. Exponentially growing cells were treated with indicated concentrations of Tempol for $48 \mathrm{~h}$. Thirty $\mu \mathrm{g}$ of protein extracts from the tested lung cells were resolved by SDS-PAGE gel, transferred to PVDF membranes, and immunoblotted with the designated antibodies. Western blot analysis shows the levels of SOD1, catalase, Trx1, TrxR1, and $\beta$-actin in A549 cells (A), Calu- 6 cells (B), and WI-38 VA-13 cells (C). 
Figure 4
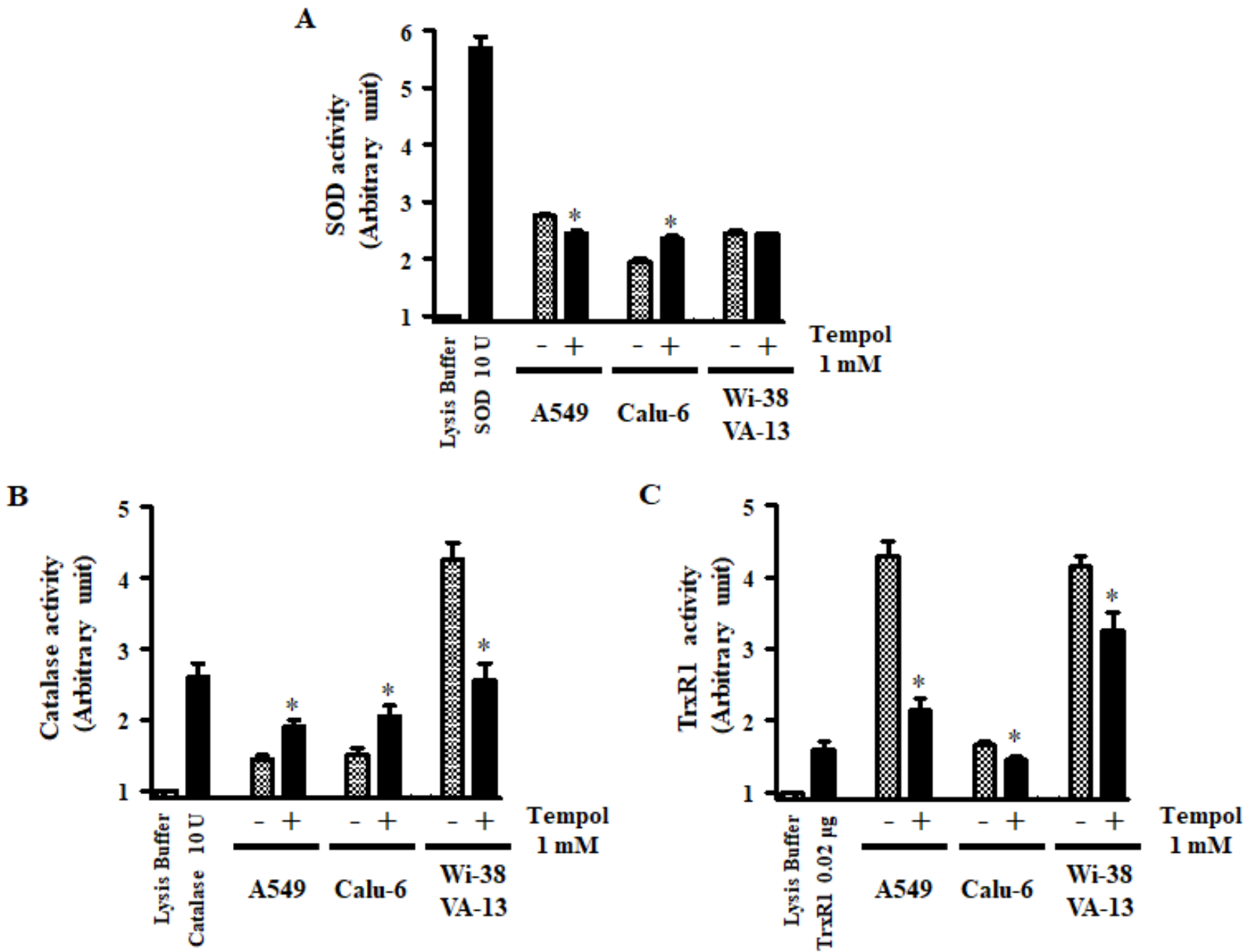

Figure 4

Effects of Tempol on SOD, catalase, and TrxR1 activity in lung cancer and normal cells. Exponentially growing cells were treated with $1 \mathrm{mM}$ Tempol for $48 \mathrm{~h}$. A: The graph shows the activity of total SOD in arbitrary units in A549, Calu-6, and WI-38 VA-13 cells. Lysis buffer indicates a negative control in this assay. SOD $10 \mathrm{U}$ indicates a positive control in this assay. B: The graph shows the activity of catalase in arbitrary units in A549, Calu-6, and WI-38 VA-13 cells. Lysis buffer indicates a negative control in this assay. Catalase $10 \mathrm{U}$ indicates a positive control in this assay. C: The graph shows the activity of TrxR1 in A549, Calu-6, and WI-38 VA-13 cells. Lysis buffer indicates a negative control in this assay. TrxR1 $0.02 \mu \mathrm{g}$ indicates a positive control in this assay. ${ }^{*} p<0.05$ compared with untreated controls. 


\section{Figure 5}

$\mathbf{A}$

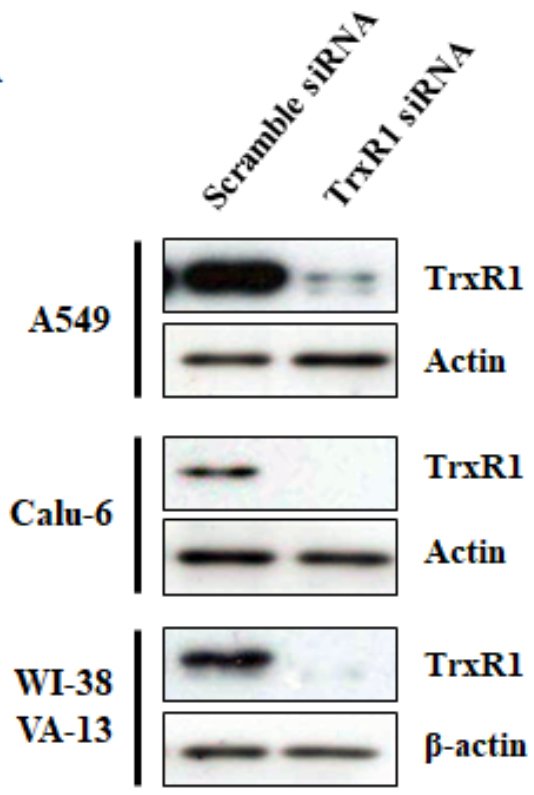

B
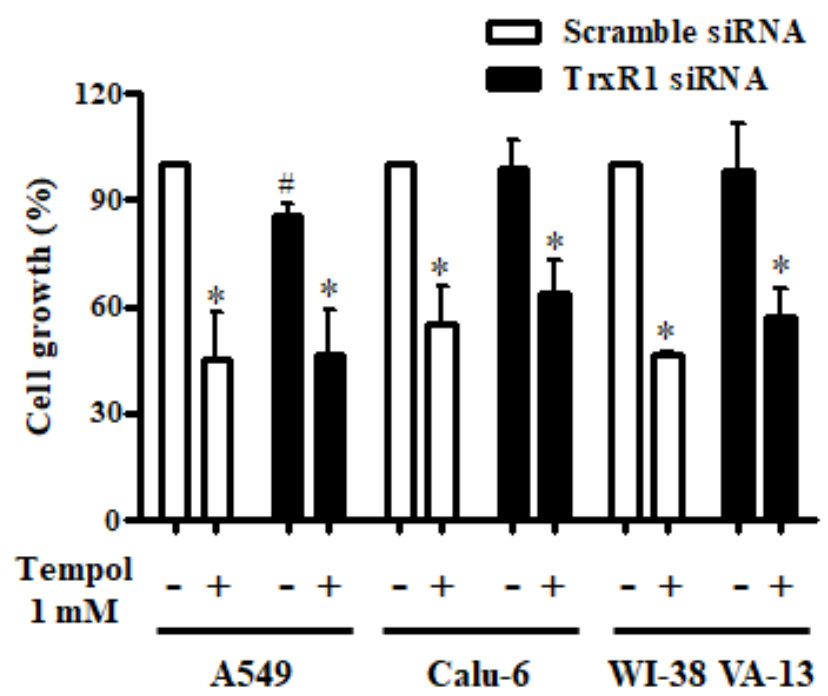

Figure 5

Effects of TrxR1 siRNA on cell growth in Tempol-treated lung cancer and normal cells. Cells (approximately $40 \sim 50 \%$ confluence) were transfected with control scramble siRNA or TrxR1 siRNA. One day later, cells were treated with $1 \mathrm{mM}$ Tempol for $48 \mathrm{~h}$. A: Thirty $\mu \mathrm{g}$ of protein extracts from the tested lung cells were resolved by SDS-PAGE gel, transferred to PVDF membranes, and immunoblotted with TrxR1 and $\beta$-actin antibodies. Western blot analysis shows the levels of TrxR1 and $\beta$-actin in A549, Calu-6, and WI-38 VA-13 cells. B: Cell growth was evaluated by MTT assays. Graph shows the growth of A549, Calu-6, and WI-38 VA-13 cells. * $p<0.05$ compared with untreated controls. \#p $<0.05$ compared with scramble siRNA-transfected and Tempol-untreated A549 cells. 
Figure 6

A

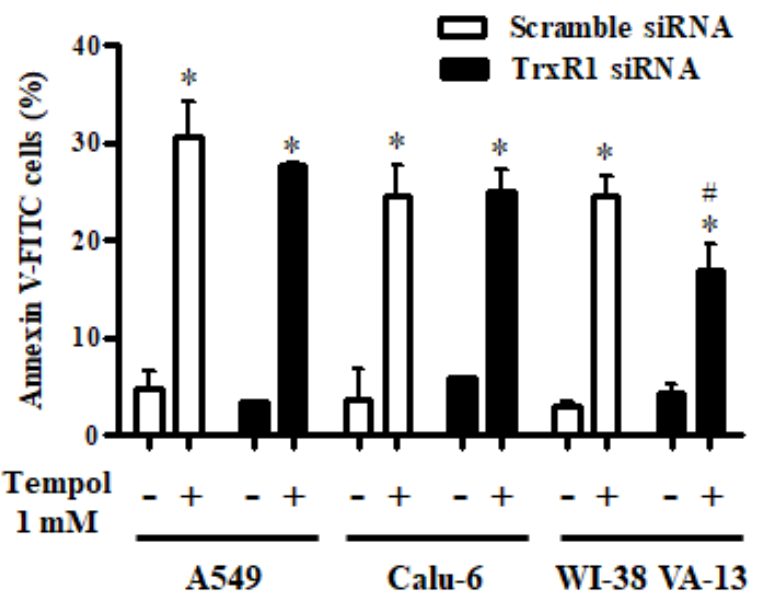

B

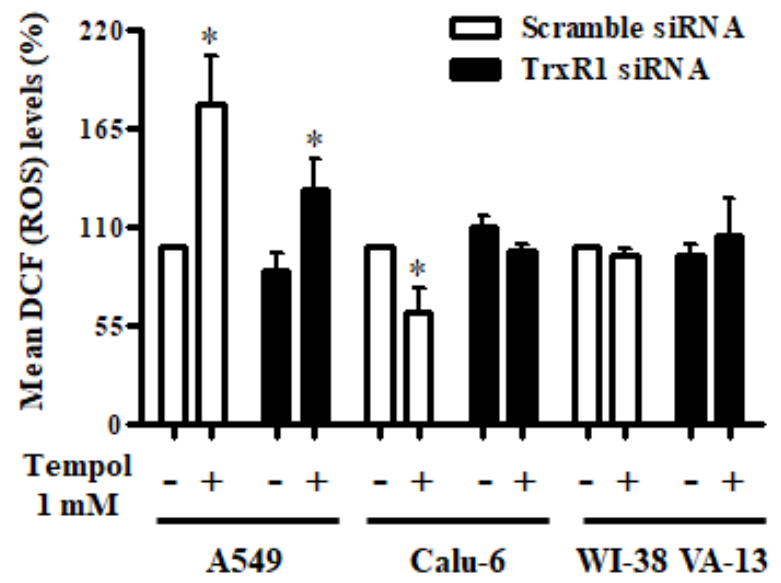

Figure 6

Effects of TrxR1 siRNA on cell death and ROS levels in Tempol-treated lung cancer and normal cells. Cells (approximately $40 \sim 50 \%$ confluence) were transfected with control scramble siRNA or TrxR1 siRNA. One day later, cells were treated with $1 \mathrm{mM}$ Tempol for $48 \mathrm{~h}$. A: Annexin V-FITC positive cells were evaluated with a FAC Star flow cytometer. Graph shows proportions of annexin V-positive cells in A549, Calu-6, and WI-38 VA-13 cells. B: Intracellular ROS (DCF) levels in the tested lung cells were measured using a FAC Star flow cytometer. Graph indicates mean ROS (DCF) levels (\%) in A549, Calu-6, and WI-38 VA-13 cells. ${ }^{*} p<0.05$ compared with untreated controls. $\# p<0.05$ compared with scramble siRNA-transfected and Tempol-treated WI-38 VA-13 cells. 


\section{Figure 7}

$\mathbf{A}$

A549 cells (48 h)

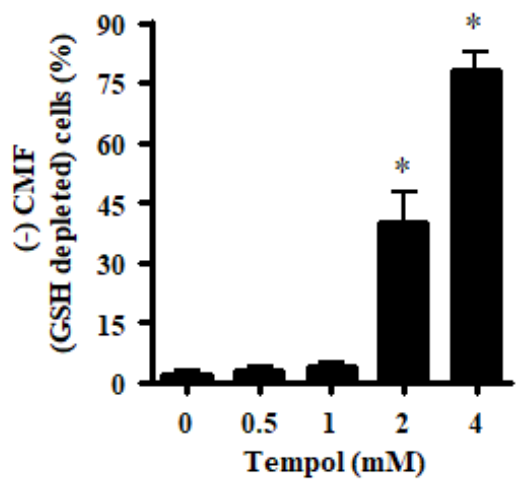

B

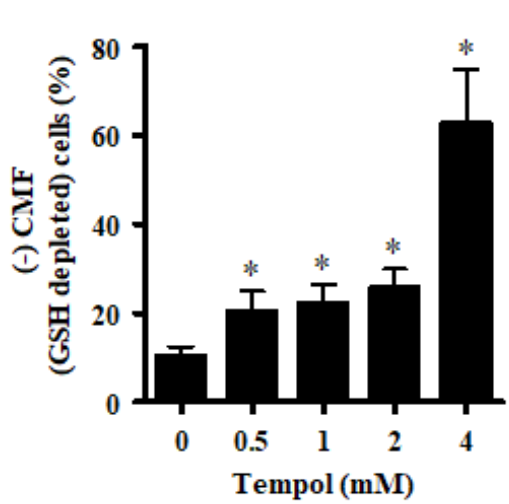

C

WI-38 VA-13 cells ( 48 h)

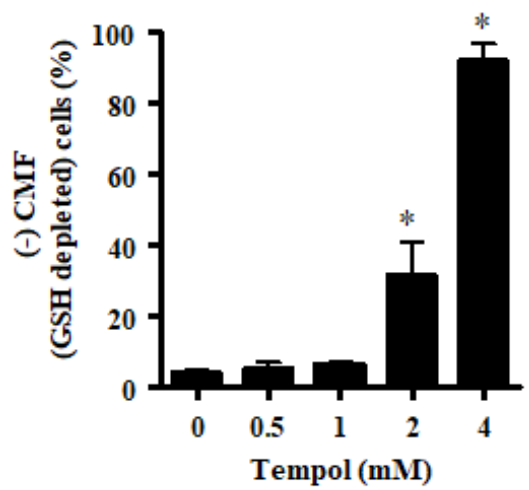

Figure 7

Effects of Tempol on intracellular GSH depletion in lung cancer and normal cells. Cells in the exponential growth phase were incubated with the indicated concentrations of Tempol for $48 \mathrm{~h}$. Intracellular CMF (GSH) levels in various lung cells were measured using a FAC Star flow cytometer. The graphs indicate the percentages of (-) CMF (GSH-depleted) A549 cells (A), Calu-6 cells (B), and WI-38 VA-13 cells (C). *p < 0.05 compared with untreated controls. 